\title{
Perception, Attitude, and Practice Toward Community Research Among Medical Students in Hadhramout University, Yemen
}

Abdullah Bin-Ghouth ( $\sim$ abinghouth2007@yahoo.com )

Hadhramout University

\section{Suha Ali Batarfi}

Hadhramout University

AbdulRahman Hashim Abonemi

Hadhramout University

Ahmed Sadeq Maknoon

Hadhramout University

Ahmad Sa'ad Alkhanbashi

Hadhramout University

Alwi Abobaker Khred

Hadhramout University

Amal Abdullah Bawazer

Hadhramout University

Areej Abdullah Ba-Jaber

Hadhramout University

Aymen Abdullah Resq

Hadhramout University

Isra'a Alwi Maknoon

Hadhramout University

Khadija Ahmed Badheeb

Hadhramout University

Maha Salah Alkathiri

Hadhramout University

Majedah Ahmed Ba-Rbaa

Hadhramout University

Mustafa Dhaiban

Hadhramout University

Omar Ali Bagumaish

Hadhramout University

Omar Saleh Basalasel 
Hadhramout University

Roua'a Abdullah Ba-rady

Hadhramout University

Souha Algadry

Hadhramout University

Tagwa Omar Bazanboor

Hadhramout University

\section{Research Article}

Keywords: HUCOM, Medical students, Undergraduate Research, Yemen

Posted Date: October 13th, 2021

DOl: https://doi.org/10.21203/rs.3.rs-958530/v1

License: (1) This work is licensed under a Creative Commons Attribution 4.0 International License. Read Full License 


\section{Abstract \\ Background}

Research is an important element in the improvement of the quality health services provided to the public. It is documented that, globally, medical students apply research in their school life. This study aimed to assess perception, attitude, and practice toward community research among medical Students at Hadhramout University.

\section{Methods}

This is a cross-sectional descriptive study was conducted among medical students in Hadhramout University in Al-Mukalla district, Yemen during the academic year 2016-2017. A self-administered pilottested questionnaire was used for data collection to assess perception, attitude, and practice toward the community research during the educational year 2016-2017.

\section{Result}

A total of 265 completed responses were received. The majority had a low Knowledge score (72\%). However, the majority had a positive attitude toward research (90.9\%). Eighty-three reported participations in research work. However, (44.4\%) expressed research interest. Many barriers were highlighted by students including; lack of time (78.4\%) and lack of training in statistics $(75.9 \%)$.

\section{Conclusion}

the majority of students had a positive attitude toward research. However, the majority of them had low knowledge scores. Also, some barriers need to be evaluated to improve the involvement of students in research activities. Lack of time was seen to be the most significant barrier to pursuing research.

\section{Background}

Research is the generation of new knowledge, science, or invention by using scientific methods and skills.

$(1,2)$ Health research training is an important component of medical education to inculcate critical thinking and reasoning skills. ${ }^{(3,4,5)}$ The scientific research methodology including topic selection, analysis and statement of the problem, literature review, formulation of the research objectives, determining study designs, study population and sample size determination, and data collection, processing, and analysis. ${ }^{(1,6)}$

The health research seeks to answer questions about the health state, disease, or risk factors; it also directs us to the causes of ill health and the effectiveness of prevention and curative intervention and 
also has an impact on health care programs policy and services. ${ }^{(7,8)}$ Moreover, research will broaden students' scientific training helping them to pursue their careers in academic medicine. ${ }^{(9)}$

During the last decade, there has been a renewed emphasis on the medical student research experience and many programs have been developed in different countries such as those two large United States programs that have sought to engage students during this critical period of training are the National Institutes of Health (NIH) sponsored Medical Student Research Fellowship Programs (MSRFs) ${ }^{(10)}$ and the Doris Duke Clinical Research Fellowship (CRF) Program, ${ }^{(11)}$ other examples are those which developed in Europe $^{(12)}$ and the Netherlands. ${ }^{(13)}$

Many students agreed that there would be no progress of humankind without the progress of science and the basis of medical progress is the use of scientific methodology and the knowledge of scientific methodology is essential for obtaining accurate objective data so the research was important in the medical field. The student who had a high attitude science will tend to be highly involved in research activities.

However, some students do not agree that research will be a part of the future, and most of them not present any research. $(2,14,15)$ Some of them agreed that some participation in research was likely valuable within their medical education so they showed the research should be being mandatory in curriculum and more time in medical school should be set aside to allow participation in research endeavors to improve research skills, attaining research publication and reinforce a teamwork spirit. $(2,14-16)$

One of the most important factors underlying any study is the researchers' beliefs, as it is these that motivate them to undertake a study in the first place. ${ }^{(17)}$ The attitude to health research stems from the researchers' curiosity and interest in a particular subject or their wish to solve a problem within a community. ${ }^{(18)}$

Students have faced many barriers when conducting the research activities as no enough time, supervisor, guidance, inadequate training in research methodology, hard to publish research during medical school, (19) uncertainty about the ability to complete a study (lack of research self-efficacy), (20) lack of research interest ${ }^{(21)}$ and limited access to data sources (i.e., internet), materials and equipment. (22)

Research is an important element in the improvement of the quality health services provided to the public. It is documented that, globally, medical students apply research in their school life. To our knowledge, there was no previous published research that addressed the issue in Yemen, and given the role of research in health care programs, this study aims to assess perception, attitude, and practice toward community research among medical students in Hadhramout University College of Medicine (HUCOM) during the academic year 2016-2017. 


\section{Methods}

Study design: Cross-sectional study among the last three years of medical students of Hadramout University in Yemen.

Study subjects: All 418 students were enrolled in the study, 154 students from the fourth year, 134 students from the fifth year, and 130 students from the sixth year.

Data collection: The data collected by using a self-administered pre-tested questionnaire which was designed and validated by experts from different universities in the Arab world. The questionnaire was divided into seven sections as the following: section 1. Personal data (Age, Gender, academic level, Name not included), section 2. student's perception toward research, section 3. students' attitude toward research, section 4. students practice toward research, section 5. barriers toward research, section 6 . relevance of the undergraduates' research and section 7. Suggestions to improve engagement of students in research.

Knowledge and attitude score: The knowledge score consisted of 6 items. Each correct answer was given a score of 1 , while zero for the wrong answer. The total knowledge score ranged from 0 to 6 and then was classified as High knowledge score (above or equal to the mean), and low knowledge (if it was below the mean). Attitudes towards research were assessed by 8 questions. The answers were measured by a 5point Likert scale ranging from strongly disagree (score 1 ) to strongly agree (score 5 ). So the range of the total attitude score was ranged from 0 to 40 , then it was classified as Positive attitude (above or equal to the mean), and negative attitude (if it was below the mean).

Data Analysis: The collected data were checked, coded, entered, and analyzed using a statistical package for social science (SPSS v20). Frequencies, mean and standard deviation are the descriptive statistical tools used as appropriate. The outcome variables were students' knowledge and attitude while gender and the academic level were the main independent variables. Statistical tests used for analysis were t-test for continuous variables and one-way analysis of variance (ANOVA) for multiple comparisons. For all purposes, the criteria of significance were considered at a P-value of 0.05 .

\section{Results}

Out of 418 questionnaires distributed, 265 students respond and return filled questionnaires giving the response rate of $66.5 \%$. (104 fourth-year students 86 fifth-year students, 75 sixth-year students). The mean age of participants is 23.9 years $( \pm 1.5)$ The majority of students were in the age group $23-26$ years, 134 of students $(50.6 \%)$ were males and $(49.4 \%)$ were females. (Table 1 ) 
Table 1

The demographical characteristic of the participant

\begin{tabular}{|c|c|c|c|}
\hline Characteristics & & Frequency & Percentage \\
\hline \multirow{3}{*}{$\begin{array}{l}\text { Age group } \\
\text { (Mean age }(23.9 \pm 1.5)\end{array}$} & $20-22$ & 37 & $14.2 \%$ \\
\hline & $23-25$ & 191 & $73.5 \%$ \\
\hline & $26-29$ & 32 & $12.3 \%$ \\
\hline \multirow[t]{2}{*}{ Sex } & Male & 134 & 50.6 \\
\hline & Female & 131 & 49.4 \\
\hline \multirow[t]{3}{*}{ Academic year } & 6 year & 75 & 28.3 \\
\hline & 5 year & 86 & 32.5 \\
\hline & 4 year & 104 & 39.2 \\
\hline
\end{tabular}

The students' knowledge about research. The highest percentage of the students (74.5\%) knew about the research concept and of them knew the importance of a representative sample (58.7\%) but only $23.3 \%$ of students understand the role of sample size in the generalizability of the obtained results. About $53 \%$ of the students be able to define descriptive statistics in contrast to inferential districts that only $34.4 \%$ of students define. Regarding research ethics, only $30.6 \%$ were able to identify the correct definition of participant students knew about the informed consent. (Table 2) 
Table 2

The student's knowledge about research

\begin{tabular}{|c|c|c|c|}
\hline \multirow[t]{2}{*}{ Question } & \multirow[t]{2}{*}{ Answers } & \multicolumn{2}{|c|}{$\begin{array}{l}\text { No and \% of } \\
\text { students }\end{array}$} \\
\hline & & No & $\%$ \\
\hline \multirow{3}{*}{$\begin{array}{l}\text { Research } \\
\text { is defined } \\
\text { as: }\end{array}$} & $\begin{array}{l}\text { a. Scientific Systematic Methodological approach for gaining new } \\
\text { information or solve a problem. * }\end{array}$ & 193 & $74.5 \%$ \\
\hline & b. Gaining new information that affects health to make interventions & 35 & $13.5 \%$ \\
\hline & c. Scientific method for data collection & 31 & $12.0 \%$ \\
\hline \multirow{3}{*}{$\begin{array}{l}\text { Sampling } \\
\text { should be: }\end{array}$} & a. Representative of the reference population. * & 152 & $58.7 \%$ \\
\hline & b. The reference population is not needed for research & 37 & $14.3 \%$ \\
\hline & c. Large enough regardless of method of selection & 70 & $27.0 \%$ \\
\hline \multirow{3}{*}{$\begin{array}{l}\text { The } \\
\text { sample } \\
\text { size is } \\
\text { needed } \\
\text { for: }\end{array}$} & a. Making data generalizable on the reference population. * & 106 & $41.2 \%$ \\
\hline & b. To be able to have a sound methodology for the research & 60 & $23.3 \%$ \\
\hline & c. To make data comparable with other studies in the same field & 91 & $35.4 \%$ \\
\hline \multirow{3}{*}{$\begin{array}{l}\text { Descriptive } \\
\text { statistics } \\
\text { are: }\end{array}$} & $\begin{array}{l}\text { a. Making conclusions about populations using data from a sample } \\
\text { drawn from the population }\end{array}$ & 74 & $28.5 \%$ \\
\hline & $\begin{array}{l}\text { b. Data that helps describe, show or summarize patterns of certain } \\
\text { phenomena. * }\end{array}$ & 138 & $53.1 \%$ \\
\hline & c. A method for testing the hypothesis & 48 & $18.5 \%$ \\
\hline \multirow{3}{*}{$\begin{array}{l}\text { Inferential } \\
\text { statistics } \\
\text { is: }\end{array}$} & $\begin{array}{l}\text { a. Making conclusions about populations using data from a sample } \\
\text { drawn from the population. * }\end{array}$ & 74 & $34.4 \%$ \\
\hline & $\begin{array}{l}\text { b. Data that helps describe, show or summarize patterns of certain } \\
\text { phenomena }\end{array}$ & 138 & $32.4 \%$ \\
\hline & c. A method to describe the variation & 48 & $33.2 \%$ \\
\hline \multirow[t]{3}{*}{$\begin{array}{l}\text { Informed } \\
\text { consent is: }\end{array}$} & $\begin{array}{l}\text { a. A document by which a study participant voluntarily confirms his or } \\
\text { her willingness to participate in particular research, after having been } \\
\text { informed of all aspects of the research that are relevant to the study }\end{array}$ & 63 & $23.8 \%$ \\
\hline & $\begin{array}{l}\text { b. A process by which a study participant voluntarily confirms his or } \\
\text { her willingness to participate in particular research, after having been } \\
\text { informed of all aspects of the research that are relevant to the study }\end{array}$ & 106 & $40.0 \%$ \\
\hline & $\begin{array}{l}\text { c. A document and a process by which a study participant voluntarily } \\
\text { confirms his or her willingness to participate in particular research, } \\
\text { after having been informed of all aspects of the research that are } \\
\text { relevant to the study. * }\end{array}$ & 81 & $30.6 \%$ \\
\hline
\end{tabular}

*Correct answer 


\section{The student's attitudes toward research.}

About $41.8 \%$ of students strongly agreed that engaging medical students in research are important. (37.4\%) strongly agreed that studying research methodology course is important. Additionally, (38.3\%) agreed that understanding research increases the burden of the overloaded curriculum on medical students. When asked about whether medical students can plan, conduct research without supervision, (33.2\%) disagreed, and only (5.8\%) strongly agreed. (30.4\%) students agreed that research participation should be compulsory to all medical students. $(39.3 \%)$ also agreed that understanding statistics is important to analyze and interpret data. (30.7\%) agreed that research is interesting and (38.9\%) that they have learned most when undertaking research. (Table 3)

Table 3

The student's attitude toward research

\begin{tabular}{|c|c|c|c|c|c|}
\hline Items & $\begin{array}{l}\text { Strongly } \\
\text { agree } \\
\text { F (\%) }\end{array}$ & $\begin{array}{l}\text { Agree } \\
F(\%)\end{array}$ & $\begin{array}{l}\text { Not } \\
\text { determined } \\
\text { F (\%) }\end{array}$ & $\begin{array}{l}\text { Disagree } \\
F(\%)\end{array}$ & 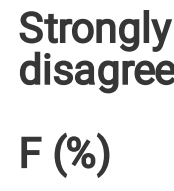 \\
\hline $\begin{array}{l}\text { Engaging medical students in } \\
\text { research is important }\end{array}$ & $110(41.8)$ & $90(34.2)$ & $31(11.8)$ & $25(9.5)$ & $7(2.7)$ \\
\hline $\begin{array}{l}\text { Studying research methodology } \\
\text { course is important }\end{array}$ & $98(37.4)$ & $96(36.6)$ & $42(16)$ & $17(6.5)$ & $9(3.4)$ \\
\hline $\begin{array}{l}\text { Understanding research increases } \\
\text { the burden of the overloaded } \\
\text { curriculum on medical student }\end{array}$ & $76(29.1)$ & $100(38.3)$ & $47(18)$ & $24(9.2)$ & $14(5.4)$ \\
\hline $\begin{array}{l}\text { Medical students can plan, conduct } \\
\text { research without supervision }\end{array}$ & $15(5.8)$ & $35(13.5)$ & $34(20.8)$ & 86(33.2) & $69(26.6)$ \\
\hline $\begin{array}{l}\text { Research participation should be } \\
\text { compulsory to all medical students. }\end{array}$ & $48(18.7)$ & $78(30.4)$ & $67(26.1)$ & $39(13.2)$ & $25(9.7)$ \\
\hline $\begin{array}{l}\text { Understanding statistics is } \\
\text { important for me to analyze and } \\
\text { interpret data }\end{array}$ & $93(36.2)$ & 101(39.3) & $39(12.8)$ & $20(7.8)$ & 10(3.9) \\
\hline I am very interested in research & $35(13.5)$ & $80(30.7)$ & $59(22.6)$ & $45(17.2)$ & $42(16.1)$ \\
\hline $\begin{array}{l}\text { I have learned most when } \\
\text { undertaking my research }\end{array}$ & $57(21.8)$ & 102(38.9) & $49(18.7)$ & $27(10.3)$ & $27(10.3)$ \\
\hline
\end{tabular}

Regarding the distribution of medical students in Hadhramout University on the Knowledge and attitude Scale. The overall mean scores of students on knowledge and attitude were $2.72 \pm 1.22$ and $27.66 \pm$ 5.31 respectively. The majority of students had low Knowledge scores (72\%). However, the majority of them had a positive attitude toward research (90.9\%). (Table 4) 
Table 4

Knowledge and attitude Scale

\begin{tabular}{|llll|}
\hline Item & & Frequency & Percent \\
\hline Knowledge & High & 73 & $28.0 \%$ \\
\cline { 2 - 4 } & Low & 188 & $72.0 \%$ \\
\hline (mean \pm SD) & $2.72 \pm 1.22$ & \\
\hline Attitude & Positive & 240 & $90.9 \%$ \\
\cline { 2 - 4 } & Negative 24 & $9.1 \%$ \\
\hline (mean $\pm S D)$ & $27.66 \pm 5.31$ & \\
\hline
\end{tabular}

The present study found that there was a significant difference between sex in terms of knowledge score with Female students $(2.99 \pm 1.24)$ having greater knowledge than males $(2.45 \pm 1.16)$ (P-value 0.000), but there was no significant difference between sex regarding attitude sore (P-value .064). (Table 5)

Table 5

Gender variation in Knowledge and attitude score regarding Research among medical students

\begin{tabular}{|lllll|}
\hline Knowledge and attitude & Male & Female & T-value & P-value \\
\hline Knowledge score mean (SD )* & $2.45 \pm 1.16$ & $2.99 \pm 1.24$ & -3.613 & $.000 \star *$ \\
\hline Attitude score mean (SD ) & $27.06 \pm 5.55$ & $28.27 \pm 5.01$ & -1.860 & .064 \\
\hline$*$ SD $=$ Standard Deviation & & & & \\
\hline$* \star$ Significant at $p$-value $<0.05$ & & & & \\
\hline
\end{tabular}

There was no significant difference regarding knowledge of and attitude to research concerning academic years (as p-value .243 and .719 respectively). (Table 6)

Table 6. Analysis of variance of knowledge and attitude score regarding research among medical students by academic years 


\begin{tabular}{|llllll|}
\hline Item & \multicolumn{2}{l}{ Academic years } & \multicolumn{2}{c|}{ T value } & P-value \\
\cline { 2 - 5 } & Fourth-year & Fifth-year & Sixth year & & \\
\hline $\begin{array}{l}\text { Knowledge score } \\
\text { mean (SD) }\end{array}$ & $2.87 \pm 1.09$ & $2.65 \pm 1.21$ & $2.57 \pm 1.40$ & 1.422 & .243 \\
$\begin{array}{l}\text { Attitude score } \\
\text { mean (SD ) }\end{array}$ & $27.62 \pm 5.56$ & $27.37 \pm 4.96$ & $28.05 \pm 5.39$ & .330 & .719 \\
\hline
\end{tabular}

The students' practice toward the research process. (48.3\%) frequently participated in developing a research proposal,( $45 \%$ ) sometimes conducting research work, $(57 \%)$ frequently participated in data collection, (39.2\%) frequently participated in data entry, (37.2\%) participated in statistical analysis, and (41.2\%) sometimes participated in writing the research final report, $(42.2 \%)$ never presented a research paper in a conference or college meeting, $(56.4 \%)$ never participated in publishing a research paper in a journal, (39.8\%) sometimes calculated the sample size, (40.1\%) never designed tables and graphs correctly. (Table 7)

Table 7 The student's practice toward research

\begin{tabular}{|llll|}
\hline Items & Frequently & Sometimes & Never \\
\hline I participated in developing a research proposal & F (\%) & F (\%) & F (\%) \\
\hline I participated in conducting research work (in general) & $127(48.3)$ & $114(43.3)$ & $22(8.4)$ \\
\hline I participated in the data collection stage & $99(38.1)$ & $117(45)$ & $44(16.9)$ \\
\hline $\begin{array}{l}\text { I participated in data entry using a statistical software } \\
\text { program }\end{array}$ & $149(57)$ & $79(30.9)$ & $31(12.1)$ \\
\hline $\begin{array}{l}\text { I participated in the statistical analysis of the obtained data } \\
\text { I participated in writing the research final report }\end{array}$ & $98(37.5)$ & $97(37.2)$ & $66(25.3)$ \\
\hline $\begin{array}{l}\text { I presented a research paper at a conference or my college } \\
\text { meeting }\end{array}$ & $82(31.3)$ & $108(41.2)$ & $72(27.5)$ \\
\hline I participated in publishing a research paper in a journal & $43(16.7)$ & $66(33.3)$ & $109(42.2)$ \\
\hline I calculated the sample size correctly & $87(33.3)$ & $104(39.8)$ & $70(26.8)$ \\
\hline I designed tables and graphs correctly & $61(23.3)$ & $96(36.6)$ & 105(40.1) \\
\hline
\end{tabular}


The varied barriers to conducting research. Time was seen to be the most significant barrier to pursuing research $(78.4 \%)$ as only $(24.6 \%)$ of participants agreed that there was adequate time set aside. While lack of training statics (75.9\%) ranked second and curriculum overload (73.4\%) came in the third majority. Furthermore, only (28\%) of Participants disagreed that there was a lack of a competent supervisor whereas $(72 \%)$ agreed that. Another minor perceived barrier agreed by the students was inadequate training in research methodology (66.5\%), poor access to the internet $(61.5 \%)$, and no interest in research (57.1\%). (Table 8)

Table 8 The student's barriers to research

\begin{tabular}{|lll|}
\hline Items & Yes & No \\
& $\mathbf{F}(\%)$ & $\mathbf{F}(\%)$ \\
\hline Lack of a competent supervisor & $188(72)$ & $73(28)$ \\
\hline Lack of fund & $152(61.5)$ & $95(38.5)$ \\
\hline Lack of personal computer & $115(44.4)$ & $144(55.6)$ \\
\hline Lack of training in statistics & $198(75.9)$ & $61(24.1)$ \\
\hline Lack of time & $203(78.4)$ & $56(21.6)$ \\
\hline Curriculum overload & $188(73.4)$ & $68(26.6)$ \\
\hline Lack of institutional motivation & $182(70.8)$ & $75(29.2)$ \\
\hline Lack of training in research methodology & $173(66.5)$ & $87(33.5)$ \\
\hline Difficulty in formulating the research questions and objectives & $122(47.3)$ & $137(52.7)$ \\
\hline No interest & $149(57.1)$ & $122(42.9)$ \\
\hline Shortage of references & $156(59.3)$ & $107(40.7)$ \\
\hline Poor Libraries & $179(67.7)$ & $84(32.3)$ \\
\hline Poor access to the internet & $161(61.5)$ & $101(38.5)$ \\
\hline
\end{tabular}

The student's relevance of the undergraduates' research. About $45.8 \%$ of students frequently addressing a common problem in their country through research, a high percentage $(61.2 \%)$ of students sometimes addressing feasible sample in research, $(44.1 \%)$ of students sometimes had enough time to complete research, $(46.7 \%)$ of students sometimes had a budget to pay their research,(43.5\%) of students had never published their researches in journals. (Table 9) 
Table 9

The student's relevance of the undergraduates 'research

\begin{tabular}{|c|c|c|c|}
\hline \multirow[t]{2}{*}{ Items } & Frequently & Sometimes & Never \\
\hline & $F(\%)$ & $F(\%)$ & $\mathrm{F}(\%)$ \\
\hline I am addressing a common problem in my country & $120(45.8)$ & $110(42)$ & $32(12.2)$ \\
\hline I am addressing feasible sample & $68(26.7)$ & $156(61.2)$ & $31(12.1)$ \\
\hline $\begin{array}{l}\text { The time that I planned is enough to complete the research } \\
\text { work and obtain valid data }\end{array}$ & $67(26.2)$ & $113(44.1)$ & $76(29.7)$ \\
\hline The budget of my research is within my ability to pay. & $81(31.5)$ & $120(46.7)$ & $56(21.8)$ \\
\hline $\begin{array}{l}\text { My researches are published or accepted for publication in } \\
\text { peer-reviewed journals }\end{array}$ & $53(20.5)$ & $96(37.1)$ & $110(43.5)$ \\
\hline
\end{tabular}

The student's suggestions to improve engagement of undergraduates in research. An (84.9\%) of students suggested that specifying sessions for supervisor research meetings must be considered, $(73.9 \%)$ of students suggested performing Research methodology course, $(76.2 \%)$ of students suggested to specify enough time in the curriculum plan to conduct research, $(71.4 \%)$ of students suggested extra training in advanced statistics, $(76.5 \%)$ of students suggested providing sources for financial support. Other suggestions were provided by the student. For example, some suggested a course on how to publish research in a journal other saw that research should be done in post-graduation due to curriculum overload. (Table10)

\section{Table 10}

The student's suggestions to improve engagement of undergraduates in research

\begin{tabular}{|c|c|c|}
\hline Items & $\begin{array}{l}\text { Important } \\
\%\end{array}$ & $\begin{array}{l}\text { Not important } \\
\%\end{array}$ \\
\hline Allocate specific sessions for supervisor research meetings & 83.0 & 14.7 \\
\hline Teaching Research methodology course & 72.8 & 25.7 \\
\hline Specify enough time in the curriculum plan to conduct research & 74.7 & 23.4 \\
\hline Provide extra training in advanced statistics & 69.8 & 27.9 \\
\hline Provide sources for financial support & 75.1 & 23.0 \\
\hline $\begin{array}{l}\text { Other suggestion: } \\
\text { 1. Course on how to publish our research in a journal. } \\
\text { 2. The research should be done for postgraduate due to curriculu } \\
\text { 3. Publish the best research in HUCOM journal. }\end{array}$ & n overload & \\
\hline
\end{tabular}




\section{Discussion}

This study addresses medical students' knowledge, attitude, and practices regarding research in medical colleges of Hadhramout University. Specifically, this study has embarked upon assessing the knowledge of medical students regarding research concepts and their attitudes toward research. Additionally, it aims to describe the variations in research practices among medical students and to identify their perceived barriers to conducting research. Finally, the study sought out to suggest recommendations for best research practices among medical students at Hadhramout University.

In the present study knowledge about research was explored. The majority of students understood the concept of research, sampling representation, and descriptive statistics. This finding was similar to research done by Louise N. Burgoyne et al. which found that the largest proportion of students in the study understood the term 'research'(20). However, students in our study couldn't understand the concepts of inferential statistics, informed consent, or the need for sampling in methodology. Majumdar $\mathrm{A}$ et al. found similar results where knowledge in areas related to data entry and analysis software and scales of measurement Performances in study designs and sampling techniques were also not satisfactory.

The result of this study revealed that the vast majority of medical students had a positive attitude toward research. However, the majority of them had low knowledge scores. This finding is inconsistent with the findings of several studies. ${ }^{(2,23,24)}$ Research has been done previously showing that students with a prior degree or research experience have better attitudes towards research (Siemens et al, 2010). ${ }^{(19)}$ On top of that, students who had a high attitude toward science will tend to be highly involved in research activities (Pruskil et al, 2009) ${ }^{(25)}$, and teaching research methodology improve the student's attitude toward research (Vujaklija et al, 2010). ${ }^{(26)}$ Since conducting research is mandatory in Hadhramout University such findings are understandable.

In the current study; female students had greater knowledge than males while the attitudes to research did not differ. Similar results were obtained by Amin et al. ${ }^{(2)}$ and Memarpouret a study. ${ }^{(22)}$ However, studies in Pakistan and the USA revealed male medical students showed a better attitude to research than their female peers. $(18,27,28,29)$ The differences may be related to data collection from different populations, variations in sample size ${ }^{(28)}$, and the increasing of acceptance female students in our medical universities.

When addressing the research practice more than three-quarters of participants reported that they have participated in research activities. This may be due to the mandatory community research course done in the early years of scientific education, and a similar policy appears to be implemented in many universities. $\left.{ }^{2}, 28\right)$ Considerations of research in the curriculum vary across countries and universities. ${ }^{17}$, 30) it was documented that involved of the medical student to research in further reformed curriculum. (25) Vujaklija et al., Khan et al., and Wang and Guo stated that assessed projects and mandatory research improve experience and training in research, have a positive impact on students, and motivate them to undertake further research in the future. $(26,27,31)$ 
The student perceived barriers in conducting research were explored. Time was seen to be the most significant barrier to pursuing research. Followed by a lack of training statics, curriculum overload, lack of a competent supervisor, poor access to the internet, and lack of competent supervisor. Similar results have also been reported in other studies. $(2,19,22,32)$ Lack of time came up as an important barrier, and students not interested in conducting research often identified time constraints as the reason. ${ }^{(32)}$ The finding revealed that $74.7 \%$ of students recommended specifying enough time in the curriculum plan to conduct research.

The student pointed out several recommendations for improvement of undergraduate engagement in research with the allocation of the specific session for research supervisor meetings having the highest recommendation. Also, they recommended being provided with extra training in advanced statistics and the provision of financial support. These recommendations were addressed by several studies. The limitation of this study includes the fact that our questionnaire did not target a full assessment of the students' knowledge. Although we exclusively used closed-ended questions. As well as, we only assessed the encountered barriers

\section{Conclusions}

This study concludes that the vast majority of medical students had a positive attitude toward research. However, the majority of them had low knowledge scores. Also, some barriers need to be evaluated to improve the involvement of students in research activities. Time was seen to be the most significant barrier to pursuing research, student suggested that specifying sessions for supervisor research meetings must be considered, most students suggested to specify enough time in the curriculum plan to conduct research they also suggested extra training in advanced statistics. Additionally, we recommend encouraging faculty to take an active interest in all aspects of student research design, data collection, statistical analysis, and preparation of scientific manuscripts. Further researches should be done to find out the motives of research conduction, which would encourage students to take part in clinical research can be of benefit. Studies like ours should be conducted regularly because they provide an assessment tool for all efforts exerted to increase student participation in research.

\section{Abbreviations}

ANOVA Analysis Of Variance

CRF Clinical Research Fellowship

HUCOM Hadhramout University College Of medicine

$\mathrm{NIH} \quad$ National Institutes of Health

SPSS Statistical Package for Social Science 


\section{Declarations}

\section{Ethics approval and consent to participate}

The research proposal was approved by Hadramout University College of Medicine (HUCOM) department of community medicine. The objectives of the study were clarified for the participant. We ensured that the information of those who agreed to participate in this study was kept in the strictest confidence and used for the benefit of the community. Students give their consent to participate verbally.

\section{Consent for publication}

Not Applicable

\section{Availability of data and materials}

All data sets are available and can be shared by requesting it from the corresponding author by email.

\section{Competing interests}

Authors declared that there is no conflict of interest.

\section{Funding}

Authors did not receive any fund from any agency.

\section{Authors' contributions}

Bin-Ghouth A and Batarfi SA contributed in research conceptualization, methodology, data analysis and writing the first and final report. Abonemi AH, Maknoon AS, Alkhanbashi AS, Khred Alwi A, Bawazer Abdulla A, Ba-Jaber Abdulla A, Resq Abdulla A, Maknoon E A, Badheeb Kh A, Maha Salah Alkathiri MA, BaRbaa MA, Dhaiban M, Omar Ali Bagumaish OA, Basalasel OS, Ba-rady RA, Algadry S and Bazanboor TO contributed in data collection, analysis and reviewing the first draft. All authors have read and approved the manuscript

\section{Acknowledgements}

Authors would like to thanks the deanship of Hadhramout University College Of Medicine (HUOM) who facilitated the work of authors during all stages of the research.

\section{References}

1. GetuDegu and TegbarYigzaw. Research Methodology. University of Gondar, Ethiopia. 2006

2. Amin T T, Kaliyadan F, Al Gattan E A, AlMjed M H, Al khanjaf h S and Mirza M. Knowledge, attitudes and barriers related to participation of medical students in research in three Arab Universities. 
Education in Medicine Journal. 2012; 4(1). Doi: 10.5959/eimj. v4i1.7. (accessed 20/2/2017)

3. Madhur $G$ and Arti A.Awareness of research among dental students in India. Journal of evaluation of medical \& dental science. 2014; 3:25. Doi: 10.14260/jemds/2014/2840. (accessed 17/2/2017)

4. Houlden RL, Raja JB, Collier CP, Clark A F and Waugh JM. Medical students' perceptions of an undergraduate research elective. Med Teach.2004; 26:7. Doi:10.1080/01421590400019542. (accessed 20/2/2017)

5. AhramM,OthmanA and ShahrouriM.Public support and consent preference for biochemical research and bio banking in Jordan. Eurj Hum Genet.2013:21:567-70. Doi: 10.1038/ejhg.2012.213. (accessed $13 / 3 / 2017)$

6. Lavis JN, Oxman AD, Moynihan R and Paulsen EJ. Evidence-informed health policy 1-Synthesis of findings from a multi-method study of organizations that support the use of research evidence. Implement Sci. 2008; 3:53. Doi: 10.1186/1748-5908-3-53. (accessed 13/3/2017)

7. Khamis N, Ibrahim R and Fetyani DM. Assessment of the research-oriented knowledge, attitude and practice of medical students and interns of the King Abdulaziz University, Jeddah and the adoption of a research-intervention educational program. RMJ. 2013;38(4):432-439. URL:http://www.ejmanager.com/mnstemps/27/27-1433255378.pdf. (accessed 20/2/2017)

8. Laskowitz DT, Drucker RP, Parsonnet J, Cross PC and Gesundheit N. Engaging students in dedicated research and scholarship during medical school: The long-term experiences at Duke and Stanford. Acad Med. 2010; 85:419-428. Doi: 10.1097/ACM.0b013e3181ccc77a. (accessed 13/3/2017)

9. Solomon SS, Tom SC, Pitchert J, Wasserman D and Powers A C. Impact of medical student research in the development of physician_scientists. Journal of Investigative Medicine 2003; 51: 149_56. Doi: 10.1136/jim-51-03-17.(accessed 13/3/2017)

10. Gallin E K and Blancq SM. Launching a new Fellowship for Medical Students: the first years of the Doris Duke Clinical Research Fellowship Program. Journal of Investigative Medicine. 2005; 53: 73_81.

11. Steiner H, Breivik J, Siebke M, Tommeras K, Figenschau K and Hansen JB. Evaluation of the medical student research programme in Norwegian medical schools. A survey of students and supervisors. BMC Med Ed 2009; 9: 43. Doi: 10.1186/1472-6920-9-43. (accessed 17/2/2017).

12. Van HJ, Hooiveld HW, Van Leeuwen T N, Vander W, Craen JM, Dekker FWet al. Scientific output of Dutch medical students. Med Teach 2010; 32:231_5. Doi: 10.3109/01421591003596592. (accessed 17/2/2017).

13. Lev EL, Kolassa J and Bakken LL. Faculty mentors and students' perceptions of students' research self-efficacy. Nurse Educ Today. 2010;30(2):169-74. Doi: 10.1016/j.nedt.2009.07.007. (accessed 17/2/2017).

14. Alghamdi K M, Moussa N A, Alessa D S, Alothimeen N and Al-Saud AS. Perception, attitude and practice toward research among senior medical students. Saudi Pharmaceutical Journal. 2014; 22:113-116. Doi: 10.1016\j.jsps.2013.02.006. (accessed 17/2/2017). 
15. Ismail M I, Bazli M Y and O'Flynn S. Study on medical student's attitude towards research activities between University College Cork and university Sins Malaysia. Procedia-Social and Behavioral sciences. (2014)116;2645-2649. Doi: 10.1016 Jj.abspro.2014.01.628. (accessed 17/2/2017)

16. Memarpour M, Potforoush A F and Ghasemi R. Evaluation of attitude to, knowledge of and barriers toward research among medical science students. Bio Med Central (2015) 14:1. dio:10.1186\s12930-015-0019-2. (accessed 20/2/2017)

17. Siemens D R, Punnen S, Wong $J$ and Kanji N. A survey on the attitudes towards research in medical school. BMC Medical Education (2010); 10:4. doi:10.1186\1472-6920-10-4. (accessed 3/3/2017)

18. Khan $\mathrm{H}$, Khawaja M, Abdul Waheed, Rauf M and Fatmi Z. Knowledge and attitudes about health research amongst a group of Pakistani medical students. BMC Med Educ. 2006; 6:54. doi:10.1186/1472-6920-6-54. (accessed 13/2/2017).

19. Park SJ, McGhee CN, Sherwin T. Medical students' attitudes towards research and a career in research: an Auckland, New Zealand study. N Z Med J. 2010;123(1323):34-42. (accessed 13/2/2017)

20. Burgoyne L, O'Flynn S and Boylan G. Undergraduate medical research: the student perspective. Medical Education Online. 2010;15: 5212. Doi: 10.3402/meo. v15i0.5212. (accessed 3/4/2017).

21. Levine RB, Herbert R S and Wright SM. Resident research and scholarly activity in internal medicine residency training programs. Journal of General Internal Medicine.2005; 20(2): 155-159. Doi; 10.1111/j.1525-1497.2005.40270.x. (accessed 17/2/2017).

22. MemarpourM, Fard A F and Ghasemi R.Evaluation of attitude to, knowledge of and barriers toward research among medical science students. Pacific Family Medicine. 2015; 14:1. Doi 10.1186/s12930-015-0019-2. (accessed 17/2/2017).

23. Abushouk A I, Hatata A Z, Omran I M, Youniss M M, Elmansy K F and Meawad A G. Attitudes and Perceived Barriers among Medical Students towards Clinical Research: A Cross-Sectional Study in an Egyptian Medical School. Journal of Biomedical Education. 2016; 5490575:7. doi:10.1155/2016/5490575

24. Majumdar A, Ganesh KS, Roy G.Knowledge. Attitude and Perception of Medical Students Regarding Community-oriented Research. Ntl J of Community Med 2015; 6(2):97-102. URL: http://www.scopemed.org/?mno=218639

25. Pruskil, S., Burgwinkel, P., Georg, W., Keil, T., \& Kiessling,C. Medical students' attitudes towards science and involvement in research activities: a comparative study with students from a reformed and a traditional curriculum. Med Teach. 2009;31(6), 254-9. Doi: 10.1080/01421590802637925

26. Vujaklija, A., Hren, D., Sambunjak, D., Vodopivec, I., Ivanis, A., Marusic, A., \& Marusic, M. Can teaching research methodology influence students' attitude toward science? Cohort study and nonrandomized trial in a single medical school. J Investig Med.2015;58(2), 282-6. Doi:

10.2310/JIM.0b013e3181cb42d9

27. Khan $H$, Khan S, Iqbal A. Knowledge, attitudes and practices around health research: the perspective of physicians-in-training in Pakistan. BMC MedEduc. 2009; 9:46. Doi: 10.1186/1472-6920-9-46 
28. Sabzwari S, Kauser S, Khuwaja AK. Experiences, attitudes and barriers towards research amongst junior faculty of Pakistani medical universities.BMC Med Educ. 2009;16:9-68. Doi: 10.1186/14726920-9-68

29. Dakik HA, Kaidbey H, Sabra R. Research productivity of the medical faculty at the American University of Beirut. Postgrad Med J. 2006; 82:462-4. Doi: 10.1136/pgmj.2005.042713

30. Chakraborti C, Bourgeois DJ, Gleeson E, Gunderson W. Identifying barriers to successful research during medical school. Med Educ Devel. 2012;2(e2):1-7. Doi: 10.4081/med.2012.e2

31. Wang, SC. \& Guo, YJ. Counseling students' attitudes toward research methods class. American Counseling Association.2011; 23:5. URL:

http://counselingoutfitters.com/vistas/vistas11/Article_30.pdf (Accessed at 12\5\2017)

32. Stockfelt, M., Karlsson, L., \& Finizia, C. Research interest and activity among medical students in Gothenburg, Sweden, a cross-sectional study. BMC Medical Education. 2016;16(1), 226. Doi: $10.1186 /$ s12909-016-0749-3 